DOI: 10.21122/2227-1031-2017-16-3-196-205

UDC 621.9.011:517.962.1

\title{
Finite Element Analysis of Centreless-Lunette Turning of Heavy Shaft
}

\author{
Yu. V. Vasilevich ${ }^{1)}$, S. S. Dounar ${ }^{1)}$ \\ ${ }^{1)}$ Belarusian National Technical University (Minsk, Republic of Belarus) \\ (c) Белорусский национальный технический университет, 2017 \\ Belarusian National Technical University, 2017
}

\begin{abstract}
Dynamics of heavy lathe tool ta be renovated has been simulated in the paper. Original turning scheme concerns finish-machining of large rotor shafts. High-positioned parts and a milling head may create dynamic problems. For this very reason FEM-simulation has been carried in static, modal and harmonic arrangements. A carrying system for shaft support consists of a bed, a support, a tool and a tailstock. A headstock is not involved in the given turning scheme. It has emerged that static and dynamic rigidity for a support is 3-4-fold less than for a shaft. Tool rigidity is decreasing from 186.5 to $11.9 \mathrm{~N} / \mu \mathrm{m}$ when passing from statics to turning rather close to support resonance. Twelve resonance modes have been evaluated in the paper. Two modes have been considered as dangerous. These modes are "shaft swinging in lunettes" (M1, $26.7 \mathrm{~Hz}$ ) and "support pecking" (M3, $54.4 \mathrm{~Hz}$ ). The paper shows excessive mechanical compliance of the bed that has insufficiently rigid ribbing and through holes. Bed filling with polymer concrete is moderately effective. Transition from twolunette $(2 L)$ scheme of shaft support to three-lunette $(3 L)$ scheme makes it possible to increase significantly rigidity in statics (by 2.09-fold) but there is a limited effect dynamics. Heights of resonance peaks are decreasing not more than 1.32-fold for M1, M3. Effect of dynamic damping has been revealed in case when high support closes with a middle lunette. The support serves as a dynamic damper. Measures for strengthening of machine tool carrying system have been analyzed in the paper. It has been established that swinging of a shaft which is to be machined according to M1 is badly blocked by passive and mechanical means. It is better to bypass a resonance while setting cutting modes. "Support pecking" resonance (M3) can be raised in the zone of high frequencies and at the same time it is possible to decrease its amplitude. This effect can be obtained while using all strengthening measures. Partial strengthening has rather low efficiency. While using a heavy machine tool three ranges are recommended for milling and turning: pre-resonance $(<20 \mathrm{~Hz})$, inter-resonance $(35-45 \mathrm{~Hz})$ and super-resonance $(>65 \mathrm{~Hz})$. The last range is preferable due to super-resonance damping of the shaft and the support as well. The next design step is to add triangle connecting rods or caissons for the bed.
\end{abstract}

Keywords: finite element method [FEM] analysis, rotation, lathe machine, rotor, rigidity, resonance, frequency response characteristic, vibration, lunette, concrete

For citation: Vasilevich Yu. V., Dounar S. S. (2017) Finite Element Analysis of Centreless-Lunette Turning of Heavy Shaft. Science and Technique. 16 (3), 196-205. DOI: 10.21122/2227-1031-2017-16-3-196-205

\section{Анализ методом конечных элементов бесцентрово-люнетного точения крупных валов}

\author{
Докт. физ.-мат. наук, проф. Ю. В. Василевич ${ }^{1)}$, канд. техн. наук, доц. С. С. Довнар ${ }^{1)}$ \\ ${ }^{1)}$ Белорусский национальный технический университет (Минск, Республика Беларусь)
}

Реферат. Смоделирована динамика тяжелого токарного станка после планируемой реновации. Оригинальная схема точения касается чистовой обработки крупных роторных валов. Высокорасположенные детали и фрезерная головка могут создавать динамические проблемы. Поэтому проведено МКЭ-моделирование в статической, модальной и гармонической постановках. Несущая система для удержания вала состояла из станины, суппорта, инструмента и задней бабки. Передняя бабка в данной схеме точения не участвовала. Оказалось, что статическая и динамическая жесткость для суппорта в 3-4 раза меньше, чем для вала. Жесткость на инструменте снижается с 186,5 до 11,9 Н/мкм при переходе от статики к точению вблизи резонанса суппорта. Оценено двенадцать резонансных мод. Две моды признаны наиболее опасными. Это «раскачка вала в люнетах» (M1, 26,7 Гц) и «клевки суппорта» (M3, 54,4 Гц). Показана избыточная податливость станины, имеющей недостаточно жесткое оребрение и сквозные отверстия. Заполнение станины полимербетоном умеренно эффективное. Переход от двухлюнетной $(2 L)$ схемы поддержки вала к трехлюнетной $(3 L)$

\section{Адрес для переписки}

Довнар Станислав Станиславович

Белорусский национальный технический университет

ул. Б. Хмельницкого, 9,

220013, г. Минск, Республика Беларусь

Тел.: +375 17 293-93-58

dovnar@bntu.by

\author{
Address for correspondence \\ Dounar Stanislav S. \\ Belarusian National Technical University \\ 9 B. Hmelnitzkogo str., \\ 220013, Minsk, Republic of Belarus \\ Tel.: +375 17 293-93-58 \\ dovnar@bntu.by
}


дает хороший рост жесткости в статике (в 2,09 раза), но ограниченный эффект в динамике. Высоты резонансных пиков снижаются не более чем в 1,32 раза для M1 и М3. Обнаружен эффект динамического гашения при сближении высокого суппорта со средним люнетом. Суппорт выступает динамическим демпфером. Проанализированы меры усиления несущей системы станка. Установлено, что раскачка обрабатываемого вала по М1 плохо блокируется пассивно-конструктивными средствами. Резонанс лучше обходить при назначении режимов резания. Резонанс МЗ «клевки суппорта» можно поднять в область высоких частот и одновременно снизить его амплитуду. Это достигается применением сразу всех мер усиления. Частичное усиление малоэффективно. Для фрезерования и точения на тяжелом станке рекомендованы три диапазона: дорезонансный (<20 Гц), межрезонансный (35-45 Гц) и зарезонансный (>65 Гц). Последний диапазон предпочтителен из-за зарезонансного демпфирования как вала, так и суппорта. Следующим конструктивным шагом должно стать добавление в станину треугольных связей или кессонов.

Ключевые слова: анализ методом конечных элементов, вращение, токарный станок, ротор, жесткость, резонанс, амплитудно-частотная характеристика, вибрация, люнет, бетон

Для цитирования: Василевич, Ю. В. Анализ методом конечных элементов бесцентрово-люнетного точения крупных валов / Ю. В. Василевич, С. С. Довнар // Наука и техника. 2017. Т. 16, № 3. C. 196-205. DOI: 10.21122/2227-10312017-16-3-196-205

\section{Formulation of problem}

Article is dedicated to providing rigid holding of very heavy shafts machined in the extra huge lathes (EHL). Such shafts are needed primarily for energy branch. Shafts are main parts of turbine and generator rotor assemblies. Bearing system for holding shaft in lathe is rather specific. It is described below as centreless-lunette scheme of turning (CLT). Statics and dynamics of CLT is not investigated. Research has been provided by computer simulation. Reliable and quite precise finite element analysis (FEA) is used [1].

Simulation was conducted for typical EHL machine tool - lathe 1A670 of KZTS brand. Investigation have been caused by planned serial renovation of these overall and costly machines. Design solutions for EHL are conservative. Composition of lathe to be simulated is rather contemporary. There are two main changes to embody during renovation. At first, centerline "headstock - tailstock" will be rose on $300 \mathrm{~mm}$ and maximal machining diameter will reach $2120 \mathrm{~mm}$. Secondly, support will be arranged as tools so milling head. Turn-milling should sharply increase output of lathe. However, shaft will be subjected to high frequency oscillations of cutting force from mill. Simulation should recommend measures for dynamic rigidity providing.

\section{Lathe geometrical model}

Machine tool of EHL type (fig. 1a) poses headstock 1 with a spindle unit. Massive faceplate 2 ( $\varnothing 2500 \mathrm{~mm}, 4.2$ ton) is placed on forward end of spindle. It transmits torque to the turned rotor shaft 3. Shaft is hold by lunettes 4 . Two lunettes at the shaft ends (4a, 4c) are always presented for investigated scheme. Third, middle lunette $4 \mathrm{~b}$ is optional. Rear, right end of shaft is sustained by tailstock 5 .

Tool 6 is placed onto support 7. Support, headstock, tailstock and lunettes are based on the bed 8 .
There are four guideways along axis $Z$ on the bed. Two far guideways (fig. 1b) are for lunette resting. Two near guideways serve for support's moving (7.9 ton). Tool can moves in the $X$ direction (transversely or radially). Axis $Y$ isn't used by lathe.

Length of typical steel shaft brought to simulation is equal $8345 \mathrm{~mm}$, diameter $-1204 \mathrm{~mm}$, weight $-31504 \mathrm{~kg}$. Shaft axis goes at $2214 \mathrm{~mm}$ above bed. Whole mass of simulated model depends on set and is not less than 120.9 ton. Gravity is taken by foots $A$ (fig. 1b) under the bed. Full length of lathe is $15.94 \mathrm{~m}$.

Structural parts of lathe are hollow and made from cast iron. Filling of hollows by concrete [2, 3] is investigated below as reinforcing measure. Fig. 1c represents concrete blocks 3 inside bed and tailstock 4 . They are showed together with shaft 1 and support 2 deformed during one of resonance excitation.

\section{Centreless-lunette scheme of turning}

Radial direction is the main to provide accuracy of turning. Finish machining on the EHL has one traditional feature. Spindle do not holds the shaft. Spindle is tied with shaft by floating chuck to translate torque and axial thrust (along $Z$ ). There is no centers between stocks and shaft ends. Flexible radial linkage between spindle and shaft is displayed (fig. 1b) as leaf system $B$.

Lunettes are very objects to fasten shaft radially. Lunettes touch shaft by radial pins (4 pieces) with slipping possibility. Every lunette stands upright near special checking circular band on the shaft. Radial retraction-extension of pins makes shaft axis parallel to guideways on the bed. Headstock is not concerned directly to accuracy (and not taken into account below). Tailstock serves mainly as brace. This is just centerless-lunette scheme of turning. 


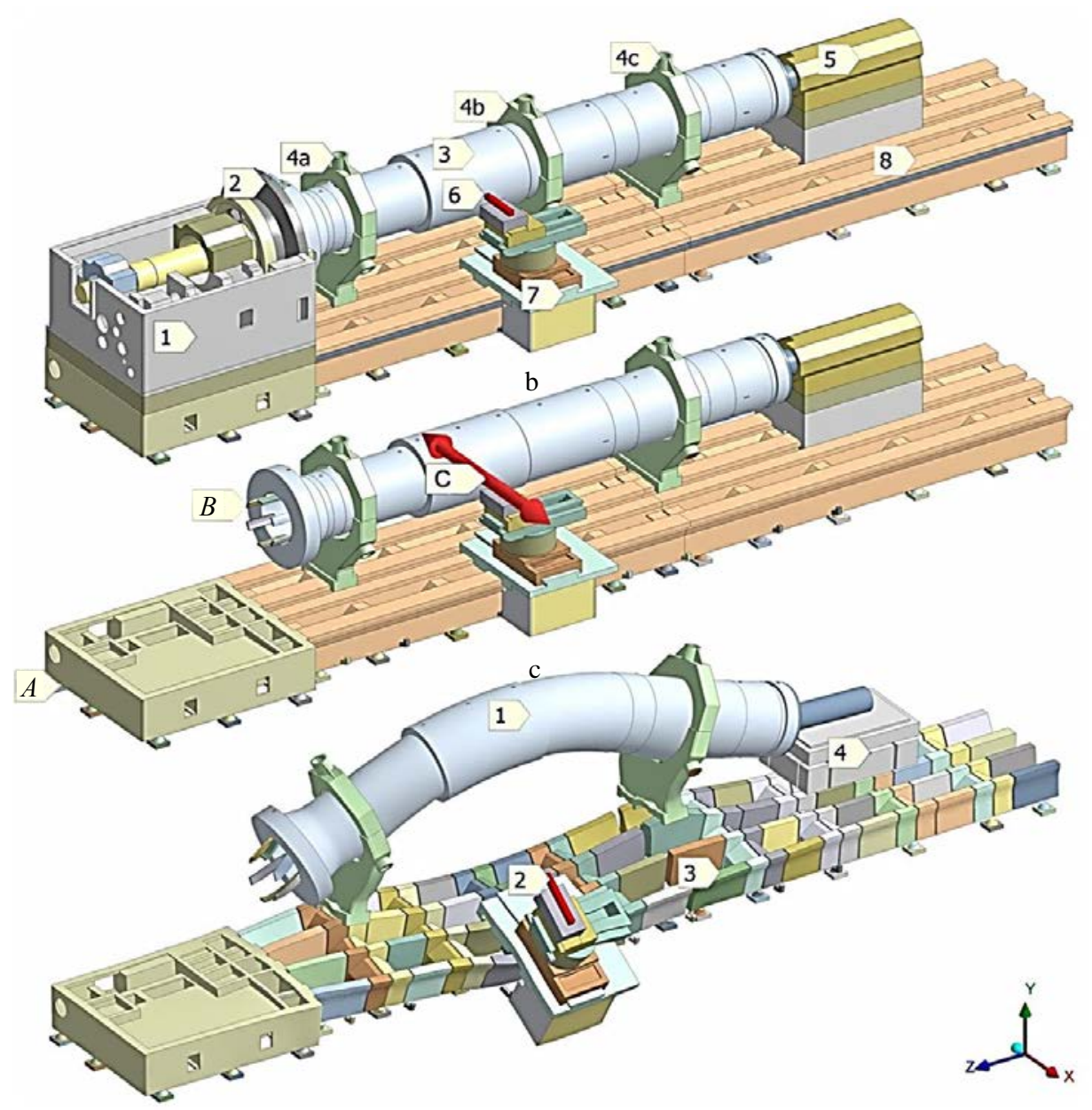

Fig. 1. Lathe (a), centreless-lunette turning (CLT) scheme (b, with mating cutting forces (MCF) as $C$ ) and eigenmode M4 resonance with concrete blocks involved (c, $63.99 \mathrm{~Hz})$

Two lunettes usually hold shaft during turning (scheme $2 L$ - fig. $1 b$ ). Third, middle lunette may be added (scheme $3 L-$ fig. 1c). Last scheme is more complicated to adjust straightness and right position of shaft axis.

It is insufficiently to hold long heavy shaft at the ends by headstock and tailstock. No less than two lunettes are need. Holding of shaft by stocks and lunettes altogether has hidden problem. These objects reveal incompatibility of deformations under gravity and cutting forces [4, 5]. Therefore, CLT scheme remains primary for practice.

\section{Boundary conditions}

\section{and finite element model parameters}

Simulation is provided on the basis of accumulated knowledge about machine tool dynamics $[5,6]$. Heavy machine tool simulation tech- nique [7-12] is used. It has approved by natural measurements [1].

Machine tool bears on 39 foots ( $A$ at fig. 1b). Vertical rigidity of every foot is high enough $J_{y}^{f t}=3600 \mathrm{~N} / \mu \mathrm{m}$ when horizontal rigidity in every direction is smaller $J_{x, z}^{f t}=1000 \mathrm{~N} / \mu \mathrm{m}$. Simplified form of floating chuck $B$ is fastened from the left to provide axial backing. Radial rigidity of chuck is small and is not taken into account.

Lathe bearing system is loaded by pair of opposite forces (fig. 1b, index $C$ ). These MCF are oriented along $X$ as transversal direction is the most important for machining precision. One force is applied to the tool tip and is equal in statics $F_{x}^{t s}=$ $=1000 \mathrm{~N}$. Second force acts on the small shaft recess opposite to the tool tip. This force $F_{x}^{s s}=-1000 \mathrm{~N}$. Both forces counterbalance each other in the lathe 
scale. Any moment do not created. With that one force acts to the support and second one deforms shaft. Direct link (FEA spring or active contact pair) between shaft and tool (on support) is absent.

Mating forces become sinusoidal in the harmonic simulation: on the tool $-F_{x}^{t t}=A \sin 2 \pi f_{t} t$, where $A=1000 \mathrm{~N}$ - force amplitude; $f_{t}$ - testing frequency in $\mathrm{Hz}$; $t$ - time; on the shaft $-F_{x}^{t s}=$ $=-A \sin 2 \pi f_{t}$ t. Frequency interval for harmonic simulation is assigned from 0 to $100 \mathrm{~Hz}$. Damping ratio coefficient is taken equal $\xi=2 \%$. It acts evenly for all bodies.

Rigidity (static or dynamic) has calculated below as ratio of force applied to displacement observed. Points for force acting and displacement registration are coincident for this work. Support and tool rigidities means the same (data calculated for tool tip). Rigidity (sustainability) and flexibility (pliability) are inverse terms.

For example, static rigidity for shaft along $X$ is equal $J_{x}^{s s}=F_{x}^{s s} / u_{x}^{s}$, where $u_{x}^{s}$ - transversal displacement in shaft recess just opposite to tool tip. As for support second force from MCF and tool tip shift are taken.

Rotodynamic effects are absent due to slow shaft spinning in practice (spindle rotational frequency $n_{s p} \leq 2 \mathrm{~s}^{-1}$ ). Slow rotation leads to low turning output. That is why question about millturning necessity derives. Emphasize, spindle rotation do not simulated here.

There are numerous contact pairs between finite element meshes of machine tool parts. All they are bonded. Free, uncontrolled slipping in the guideways is considered prevented for parts weight. Finite element model is fully linear and scalable.

Main materials for simulation are cast iron (structural parts), steel (lunettes, tailstock quill, tool, toolholder etc.), concrete (polymer concrete).
Mechanical properties are given in tab. 1. Concrete may be switched on or off in hollows. Bonded contact between concrete blocks and inner walls of bed or tailstock is provided anyway.

Table 1

Mechanical properties of model materials

\begin{tabular}{|l|c|c|c|}
\hline \multicolumn{1}{|c|}{ Material } & $\begin{array}{c}\text { Young's } \\
\text { modulus } E, \\
\mathrm{MPa}\end{array}$ & $\begin{array}{c}\text { Specific } \\
\text { density } \rho, \\
\mathrm{kg} / \mathrm{m}^{3}\end{array}$ & $\begin{array}{c}\text { Poisson's } \\
\text { coefficient } \mu\end{array}$ \\
\hline Grey cast iron & 130 & 7200 & 0,28 \\
\hline Steel & 200 & 7850 & 0,30 \\
\hline $\begin{array}{l}\text { Concrete (mineral } \\
\text { or polymer) }\end{array}$ & 30 & 2300 & 0,18 \\
\hline
\end{tabular}

Set of parameters above will be called basic variant $B V$. It means two-lunette shaft holding $2 L$ and empty cavities inside structural parts.

\section{Static rigidity for shaft and tool for centerless-lunette of turning}

Rigidity data is showed in tab. 2 for $B V$, threelunette scheme $3 L$, two-lunette scheme with concrete inside bed and tailstock $(2 L+C)$ and for reference variant $2 L+R B$, where two lunettes are based on the infinitely rigid invisible bed.

Ratio coefficient $k_{x}^{s s}$ is calculated in tab. 2. It shows relation between shaft and support rigidities in transversal direction. Shaft proves always 3-4 time more rigid than support. It partially derives from lofty support appearance - it will be rose at $300 \mathrm{~mm}$ in renovation. Meanwhile support rigidity is sufficient $(186.5 \mathrm{~N} / \mu \mathrm{m})$. It is far higher from $20 \mathrm{~N} / \mu \mathrm{m}$ level. That level is regarded [13-15] as border for self-propelled oscillation popping and cutting stability losing. It leads usually to rough chatter vibration during machining. Value $J_{\text {norm }}^{s, d} \geq$ $\geq 20 \mathrm{~N} / \mu \mathrm{m}$ is respected as secure condition for static and dynamic situations.

Static rigidity along transversal direction $(X)$ on shaft and support for different variants of shaft holding

\begin{tabular}{|l|c|c|c|c|}
\hline \multirow{2}{*}{\multicolumn{2}{c|}{ Parameter }} & \multicolumn{4}{|c|}{ Variant } \\
\cline { 2 - 5 } & $1(B V)$ & 2 & 3 & 4 \\
\cline { 2 - 5 } & $\begin{array}{c}\text { 2 lunettes }(2 L), \\
\mathrm{N} / \mu \mathrm{m}\end{array}$ & $\begin{array}{c}\text { lunettes }(3 L), \\
\% \text { to } B V\end{array}$ & $\begin{array}{c}\text { 2 lunettes and concrete } \\
(2 L+C), \% \text { to } B V\end{array}$ & $\begin{array}{c}\text { 2 lunettes on rigid bed } \\
(2 L+R B) \% \text { to } B V\end{array}$ \\
\hline Shaft rigidity $J_{x}^{\text {ss }}$ & 778,6 & 207 & 145 & 252 \\
\hline Support (tool) rigidity $J_{x}^{\text {sus }}$ & 186,5 & 133 & 209 & 345 \\
\hline Ratio coefficient $k_{x}^{\text {ss }}=J_{x}^{\text {ss }} / J_{x}^{\text {sus }}$ & 4,17 & 6,47 & 2,89 & 3,05 \\
\hline
\end{tabular}


Scheme $3 L$ increases shaft static rigidity as twice. It derives from middle lunette proximity to point of imaginary measuring. Tool rigidity grows in 1.33 times simultaneously. Hence support and middle lunette interact indirectly through the bed.

Bed reinforcement by concrete pouring (variant 3, tab. 2) enhances support rigidity in 2.09 times. But numerous vertical through holes for chip removing remain opened. Infinitely rigid bed $R B$ rises support rigidity in 3.45 times (variant 4). Difference between variants 3 and 4 pointed out vertical holes as issue for bed flexibility.

One could see holes (fig. 1c) between rows of concrete blocks (near 8, e. g.). Hole squareness excludes triangle links inside bed. Therefore, bed demonstrates shear flexibility even after concrete filling.

\section{Modal analysis}

Twenty eigenmodes were located for shaft bearing system in the frequency interval up to $120 \mathrm{~Hz}$. There are axial $(Z)$ and multi-wave resonances in the top half of interval. Though, transversal $(X)$ and vertical $(Y)$ eigenmodes are more significant for accuracy and stability of cutting. Such modes are placed in the bottom half of frequency interval.

There are four eigenmodes to pay attention (tab. 3). They are showed at fig. 2 (eigenmodes M1, M2, M3) and fig. 1c (M4). Here resonant excitations spread in the machine tool scope. So these eigenmodes are called whole-machine ones [8-11]. Resonant system M1-M4 is stable and is revealed as for two-lunette turning so for three-lunette one.

Very low-frequency eigenmode M1 consists in transversal shaft swinging. All lunettes oscillate at the same phase in the $X Y$ plane. As seen on fig. 2, a lunette movement is caused not so much with it bending as with bed deformation. Shift to threelunette scheme rises M1 frequency only at $19 \%$ (from 26.7 to $31.8 \mathrm{~Hz}$ ). It indirectly shows dynamic flexibility of bed.

Eigenmode M2 (fig. 2b) presents counter-phase moving of shaft ends 1 and 4 along $X$ (anti-nodes). Single node is placed near point 3 . It takes half of sinusoid period. Shaft inaccuracies caused by M2 depends on tool position and will be higher near anti-nodes.

Eigenmode M3 (fig. 2c) reveals pliable behavior of the bed beneath support. Two concerned guideways become strongly deformed. Support gets opportunity for pecking movement in $X Y$ plane (mainly along $X$ ). Increased support height (additional $300 \mathrm{~mm}$ at renovation) promotes oscillation scope.

Eigenmode M4 (fig. 1c) consist of two coordinated movements - vertical "horse-shoe style" shaft bending and transversal support stroke. Such components may create inclined elliptic trajectory for tool. It potentially threaten excitation of selfpropelled oscillations (chatter) and losing of cutting stability $[5,6,13,14]$.

Eigenmodes M1 and M3 are most dangerous for its transversal direction $(X)$ implementation. Shaft and tool displacements reflect straightly onto machined radius. Vertical vibrations $(Y$, shaft bending according M4 e. g.) are tangent to radius and distort it slightly.

Eigenmodes M1 and M3 affect each other weakly. It may conclude by fig. 2a, b. Resonance by M1 spring up into dynamic subsystem "shaft on lunettes" and M3 - in subsystem "support onto bed". Different factors should be essential for each eigenmode.

Whole-machine eigenmodes with shaft and support participation

\begin{tabular}{|c|l|c|c|c|}
\hline \multirow{2}{*}{ Eigenmode } & \multirow{2}{*}{ Eigenmode name } & \multicolumn{3}{|c|}{ Eigenmode frequency, Hz } \\
\cline { 3 - 5 } & & Basic variant $(2 L)$ & Three lunette (3L) & Rigid foots and $2 L$ \\
\hline M1 & Shaft swinging (lunettes in phase) & 26,7 & 31,87 & 32,78 \\
\hline M2 & Shaft end waving (lunettes in antiphase) & 49,25 & 50,45 & 61,41 \\
\hline M3 & Support pecking & 54,48 & 65,41 & 88,57 \\
\hline M4 & Horse-shoe & 58,51 & 80,26 & 72,59 \\
\hline
\end{tabular}




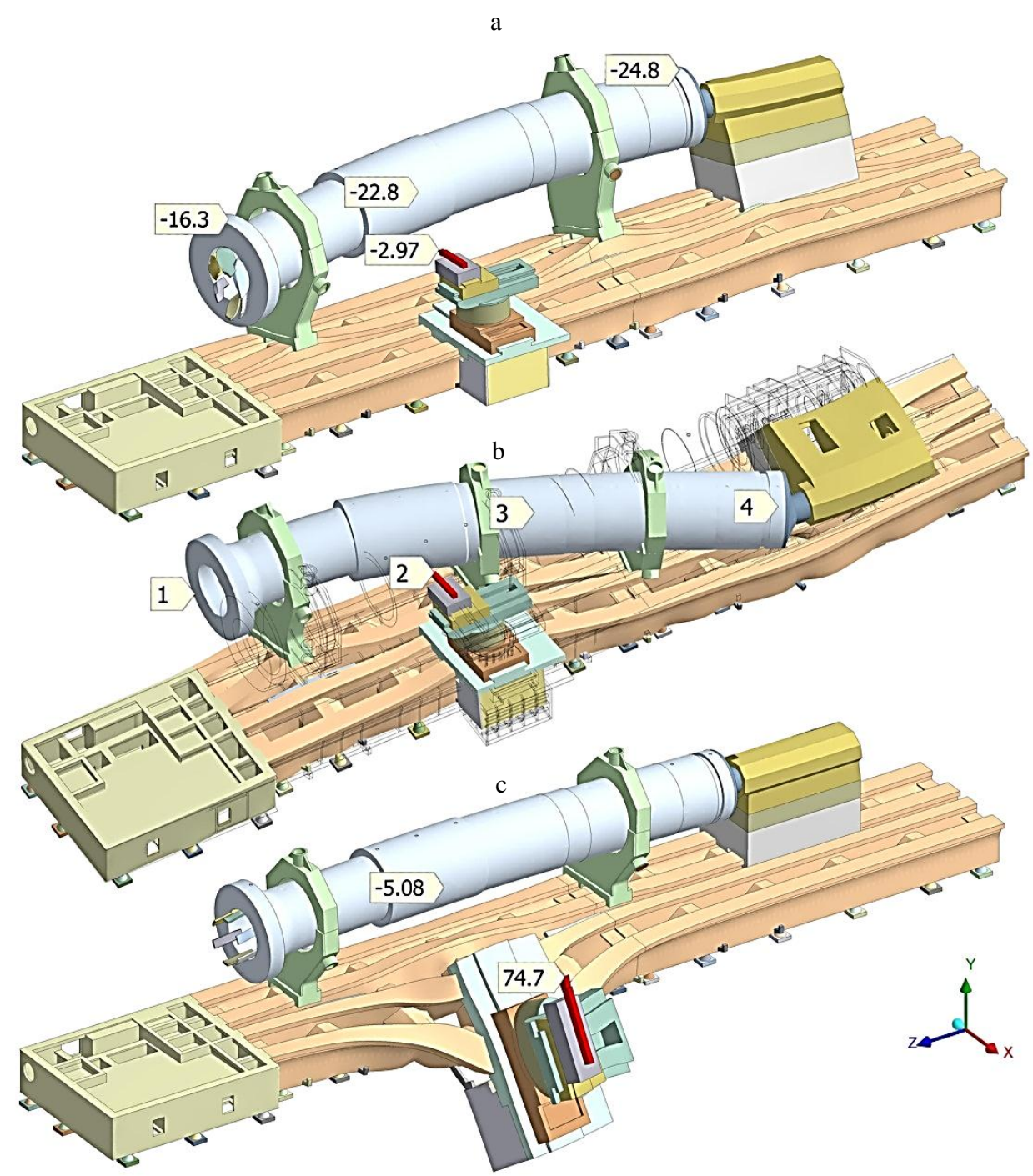

Fig. 2. Resonance excitation by mating cutting forces according to eigenmodes M1 (a, $2 L, 26.7 \mathrm{~Hz}$ ), M2 (b, $3 L, 50.45 \mathrm{~Hz}$ ), M3 (c, $54.48 \mathrm{~Hz})$. Displacements in $\mu \mathrm{m}(\times 45000)$

\section{Harmonic analysis and frequency response function}

Resonance is excited by appropriate forces on the basis of some eigenmode. Excitability of eigenmode depends on site and direction of force acted. Mating cutting forces MCF has applied in this work at tool and shaft as described above. Sequence of specific frequency tests gives possibility to create frequency response function (FRF). MCF is the input signal for FRF and displacements $(X)$ of tool tip or shaft (near recession) are the output values.

FRF for basic variant $B V$ is showed at fig. 3 . Peaks for M1 "shaft swinging” and M3 "support pecking" are most powerful. Shaft amplitude reaches $22.95 \mu \mathrm{m}$ in the $\mathrm{M} 1$ resonance. Accordingly dynamic rigidity fall in $X$ direction to the level $J_{X, M 1}^{s d}=43.6 \mathrm{~N} / \mu \mathrm{m}$. Resonance M3 is the strongest one (amplitude on tool tip $84.06 \mu \mathrm{m}$ ). Dynamic rigidity lessens as low as $J_{x, M 3}^{t d}=43.6 \mathrm{~N} / \mu \mathrm{m}$. Such level is insufficient for providing turning accuracy and cutting process stability.

Dynamic rigidity lowers relatively to static one in $15-17$ times $(\xi=2 \%)$ as for shaft (M1) so for support (M3). Shaft remains in 3.5-4.5 times more rigid than support at the M1, M3 peaks. Resonances M2 and M4 manifest themselves as relatively faint and seen mainly FRF curve for shaft. They border from left and right strong "support pecking” resonance M3. 


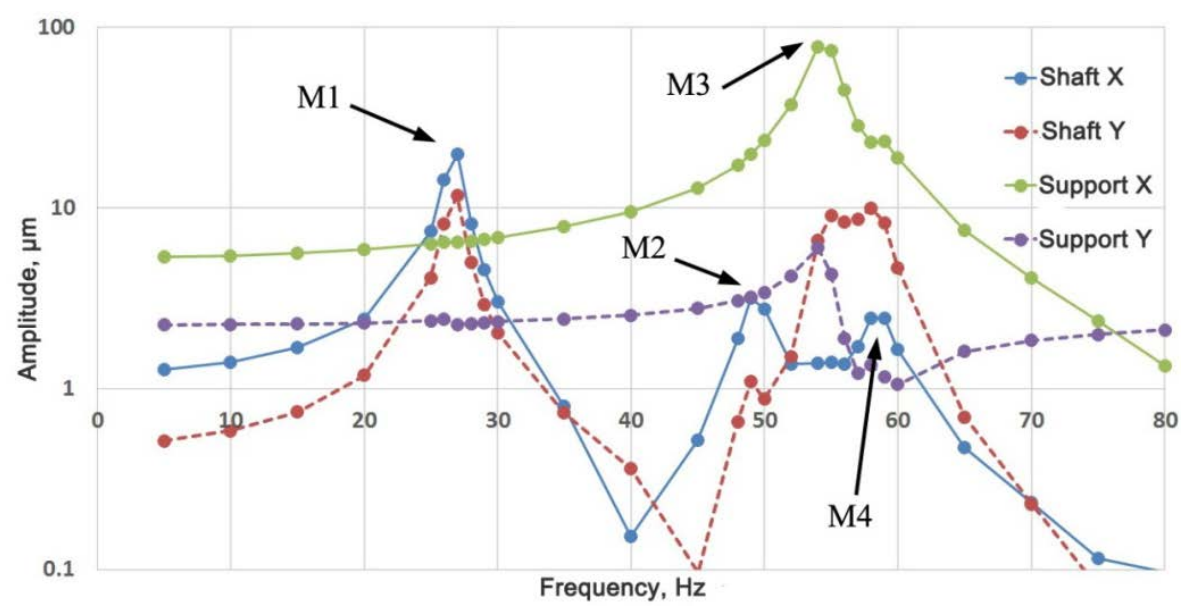

Fig. 3. Frequency response function for shaft and support displacements along axes $X$ and $Y$ under mating cutting forces action along $X$ ( $B V$, logarithmic scale for ordinate)

FRF curve "support $Y$ " goes much more lower than "support $X$ ". Therefore crossing " $X$-force to $Y$-displacement" is weak. It is good feature for support dynamic subsystem. Both curves mentioned above poses single peaks M3. Static (preresonant) frequency interval extends for support to the left from M3. To the right from M3, support oscillations are quickly damped due to frequency growth in the post-resonant interval.

Shaft FRF's for $X$ and $Y$ directions are similar. Crossing " $X$ to $Y$ " may be stated. It means force applied to shaft along $X$ excites not only transversal vibrations, but also vertical oscillations. Such conjunction is dangerous for chatter arising.

Shaft FRF's on fig. 3 have double peak shape. Hence, shaft machining is recommended into one of three "calm" intervals: pre-resonant $(<20 \mathrm{~Hz}$, to the left of M1 peak), inter-resonant (35-45 Hz, between M1 and M2 peaks) and post-resonant ( $>65 \mathrm{~Hz}$, to the right of M4 peak).

It is important to reinforce dynamically bearing system of lathe. It should develops as resonance peaks lowering and shifting of peaks to the higher frequencies. Let it see how FRF changes for threelunette scheme of shaft holding (3L, fig. 4).

Middle lunette mounting decreases amplitude of M1 peak in 2.78 times at once, when resonant frequency grows only at $19 \%$. Additional FEA revealed surprise local effect caused by proximity of support and middle lunette. They both fasten flexible bed guideways. Moreover, support works as tuned mass damper towards lunette. Lunette amplitude grows to $17.34 \mu \mathrm{m}$ if support were going at left or right. Nevertheless support dynamic rigidity increases no less than 1.32 times if $2 \mathrm{~L}$ scheme were changed to $3 L$ one.

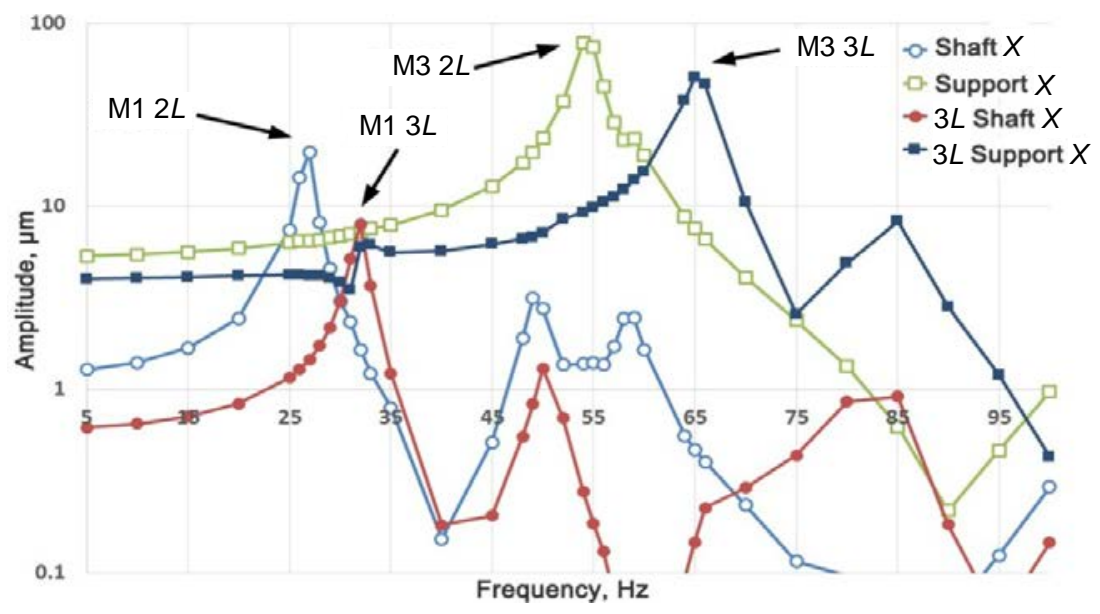

Fig. 4. Frequency response function for shaft and support displacements in case of three-lunette scheme $3 L$ (curves "shaft $X$ ”, "support $X$ ” are for references and touches to $2 L$; logarithmic scale for ordinate) 
M3 resonant frequency rises at $20 \%$. Dynamic rigidity on the tool tip increases for $3 L$ scheme in 1.6 times (in case of lunette to support proximity). Rigidity goes up to level $19.15 \mathrm{~N} / \mu \mathrm{m}$. It became sufficient for chatter prevention even at resonance.

Three-lunette scheme $3 \mathrm{~L}$ should be recommended for practice for reasons of dynamics. It effect will change from moderate to strong depends of support position relatively to lunettes. Scheme is inconvenient in part of lunette alignment.

\section{Reinforcement measures for bearing system}

Sequence of measures to hold shaft faster has been simulated. Measure F2 means doubling rigidity of each foot under lathe bed. It was reached by changing modelling material properties. In practice more foots of bigger dimensions may be used.

Measure B2 consist in doubling of Young's modulus for bed material and cast iron of tailstock. It can be fulfilled by changing material from gray cast iron to high-duty iron, steel, thickening walls etc.

Measure L2 suppose Young's modulus doubling for lunettes. Lunette reinforcement may be achieves not only by wall thickening and material redistribution, but by high-strength lightweight materials using (composite e. g.).
Measure $C$ means concrete pouring into bed and tailstock cavities (concrete properties according tab. 1). Measure $R B$ is theoretical - infinitely rigid bed for lunettes and tailstock.

Initial lathe bearing system $(B V)$ has been reinforced through new measures by steps (tab. 4). Final step 6 provides infinitely rigid bed. It shows some limit of reinforcement. Polygon lines (fig. 5) $f_{1}$ and $f_{3}$ are concerned to resonant frequencies M1 and M3 respectively. Polygons "shaft $X$ M1" and "support $X$ M3" demonstrate resonant amplitudes in transversal direction $X$.

Reinforcement measure sequence was reshuffled several times compare with tab. 4 . All the time each measure gives it inherent effect no way the step to apply. Therefore, synergetic interaction between measures is not notable.

Fig. 5 demonstrates that each reinforcement measure is positive in dynamics sense. Resonant frequencies grow and peaks are weakened. Yet rigidity doubling for foots (step 2) and lunettes (step 4) gives a small effect. All curves are near horizontal at the related ranges 1-2 and 3-4 (especially). Hence, lunette reinforcement is not needed. Foot strengthening is desirable for support rigidity but it is second order measure.

Reinforcement steps and measures activated in accumulated manner

\begin{tabular}{|c|c|c|c|c|c|c|}
\hline Steps of reinforcement & 1 & 2 & 3 & 4 & 5 & 6 \\
\hline Measures applied (accumulated) & $B V$ & $F 2$ & $F 2+B 2$ & $F 2+B 2+L 2$ & $F 2+B 2+L 2+C$ & $L 2+R B$ \\
\hline
\end{tabular}

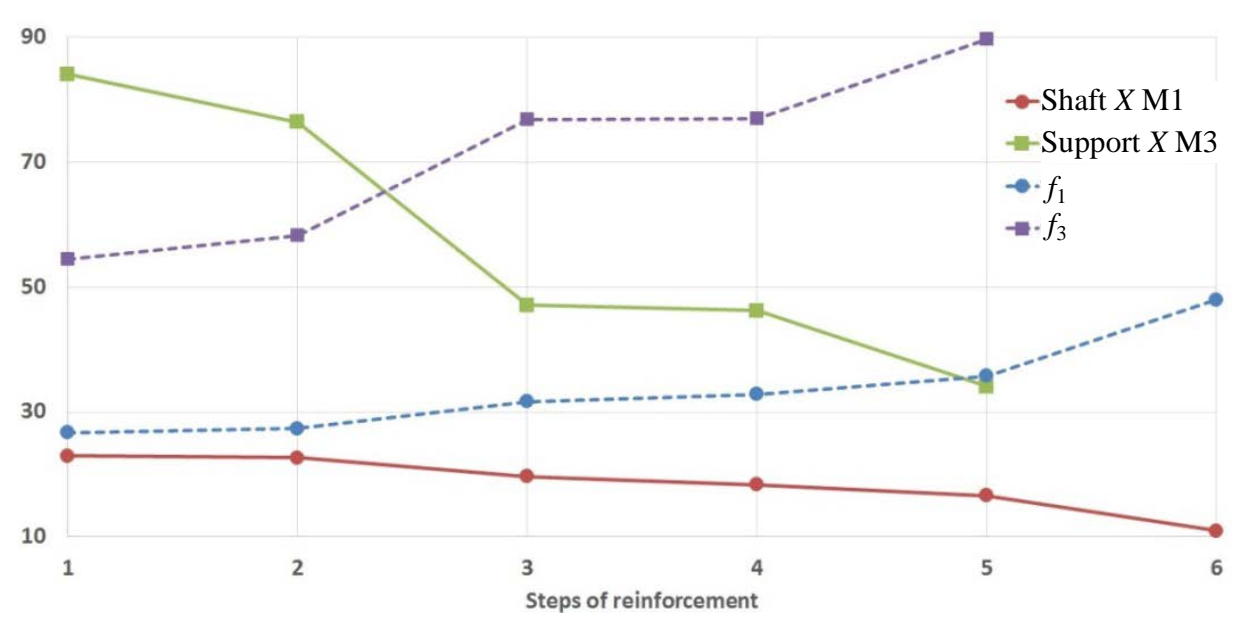

Fig. 5. Amplitude and frequency changing for resonances M1 and M3 according to sequence of reinforcement steps (tab. 4). Ordinate dimension: $\mu \mathrm{m}$ - for amplitude polygons "shaft $X$ M1", "support $X$ M3"; $\mathrm{Hz}$ - for polygons related to resonance frequencies $f_{1}, f_{3}$ 
Concrete pouring into bed and tailstock (range 4-5) is rather effective measure. Frequency of M3 "support pecking" resonance enhanced at $16.5 \%$, vibration amplitude lowers at 1.35 times. However most strong measure is doubling of bed rigidity (2-3). Eigenmode M3 amplitude came down at 1.62 times and resonant frequency rises at $31.8 \%$ at the same time. Therefore bed itself should be reinforced. Chip removing system should be revised for vertical holes closing. These windows gives to bed too more undesirable pliability.

M3 resonance answers to reinforcement measures. Rising at 1.64 times is obtained for frequency $f_{3}$. Tool rigidity increased threefold - from 11.9 to $29.4 \mathrm{~N} / \mu \mathrm{m}$. Cutting instability prevented even at the resonant frequency.

"Shaft swinging" resonance M1 reacts to reinforcement weaker. Rigidity elevation in 1.38 times only achieved at range $1-5$. Resonant frequency was rose at 1.33 times. Sharp turning of lines before "rigid bed" range 5-6 points out reserves for better shaft holdings. Lathe bed should redesigned as more monolithic with triangle inner links to withstand shear. As for existing bed, it would better to omit M1 resonance by cutting speed correction.

\section{CONCLUSIONS}

1. Two excitable resonances M1 "shaft swinging” and M3 "support pecking” are disclosed. Pliability of the bed is main issue for this lathe. Even concrete filling could not definitely helps. Three frequency intervals are recommended for turning and milling at huge lathe: pre-resonant $(<20 \mathrm{~Hz}$ ), inter-resonant (35-45 Hz) and post-resonant $(>65 \mathrm{~Hz})$. The last one is more suited for strong post-resonant damping effect, touched as shaft so support with tool.

2. Systematic investigation of reinforcing measures is provided. For essential dynamic rigidity improvement, all reinforcement measures should be applied at the same time, as a set. It gives possibility of stable machining at frequencies near support resonance (M3). Turning-milling near shaft resonance (M1) is possible for three-lunette bearing system.
3. For further developing, inner ribbing system of lathe bed should be redesigned with triangle fins addition. Other way of bed reinforcement is to create caissons inside it and to close all top and side windows.

\section{REFERENCES}

1. Zenkevich O., Morgan K. (1983) Finite Elements and Approximation. New York, John Wiley \& Sons. 328 (Russ. ed.: Zenkevich O., Morgan K. (1986) Konechnye Elementy i Approksimatsiia. Moscow, Mir. 312).

2. Brailovsky M. I., Voskoboynik A. G., Voskoboynik A. A. (2010) Metal Concrete Basic Structures of Metal Cutting Machines. Kolomna, Voentekhizdat Publ. 76 (in Russian).

3. Simon M., Grama A. L., Ganea M. (2012) Study of Improving Static Rigidity on Machine Tool Structure Using Concrete Component. The $6^{\text {th }}$ International Conference INTER-ENG 2012. Interdisciplinarity in Engineering. Romania, “Petru Maior” University of Tîrgu Mureş, 26-29.

4. Dovnar S. S. (2017) Virtual Investigation of Static Deformations in Rotor Shaft of Super Heavy Turning Lathe. Teoreticheskaya i Prikladnaya Mekhanika: Mezhdunar. Nauch.-Tekhn. Sbornik [Theoretical and Applied Mechanics. International Scientific and Technical Collected Volume]. Minsk, BNTU, (32), 72-78 (in Russian).

5. Kudinov V. A. (1967) Dynamics of Machine Tools. Moscow, Mashinostroyenie Publ. 359 (in Russian).

6. Kozlovsky N. A., Zaykin M. P. (1986) Rigidity and Vibration Resistance in Heavy Milling Machines. Minsk, Nauka i Tekhnika Publ. 135 (in Russian).

7. Turomsha V. I., Dovnar S. S., Truskovsky A. S., Shumsky I. I. (2012) Rigidity Balance of Mill-Drill-Bore Machine with Equally-Spaced Location of Spindle Head. Vestn. Gomel'skogo Gos. Tekhn. Un-ta imeni P. O. Sukhogo [Bulletin of Gomel State Technical University Named After P. O. Sukhoi], (3), 19-29 (in Russian).

8. Dovnar S. S., Yakimovich A. M., Kovaleva, I. L., Shumsky I. I. (2014) Harmonic Analysis of Portals for Heavy "Gantry-Type” Peripheral Milling Machines While Using Finite Element Method. Vestnik Polotskogo Gosudarstvennogo Universiteta. Seriya B. Promyshlennost' [Bulletin of Polotsk State University. Series B. Industry], (11), 2536 (in Russian).

9. Vasilevich Yu. V., Dovnar S. S., Shumsky I. I. (2014) Modal Analysis of Carrying System for Heavy Horizontal Multi-Purpose Machine while Using Finite Element Method. Nauka i Tekhnika [Science \& Technique], (4), 14-24 (in Russian).

10. Vasilevich Yu. V., Dovnar S. S., Truskovsky A. S., Shumsky I. I. (2015) Simulation and Analysis of Dynamics for Carrying System of Mill-Drill-Bore Machine with Mono Column. Nauka i Tekhnika [Science \& Technique], (3), 9-19 (in Russian).

11. Dounar S. S., Sokorov I. O., Truskouski A. S., Shumsky I. I., Karabaniuk I. A. (2015) FEA Analysis of Portal Design 
Variants Influence on Dynamics of Portal Machine Tool. Mashinostroenie: Respublikanskii Mezhvedomstvennyi Sbornik Nauchnykh Trudov. [Mashinostroenie. Republican Interdepartmental Collection of the Scientific Works Proceedings], 29, 14-22 (in Russian).

12. Vasilevich Yu. V., Dounar S. S., Karabaniuk I. A. (2016) Finite-Element Analysis of Influence of Concrete Filling Material on Dynamic Rigidity of Heavy Machine Portal. Nauka i Tekhnika [Science \& Technique], 15 (3), 233-241 (in Russian). DOI: 10.21122/2227-1031-2016-15-3-233-241.

13. Lopez de Lacalle L. N., Lamikiz A. (2009). Machine Tools for High Performance Machining. Springer. 442. DOI: 10. 1007/978-1-84800-380-4.

14. Gradišek J., Kalveram M., Insperger T., Weinert K., Stépán G., Govekara E., Grabec I. (2005) On Stability Prediction for Milling. International Journal of Machine Tools and Manufacture, 45 (7-8), 769-781. DOI: 10.1016/j. ijmachtools.2004.11.015.

15. Schmitz T., Duncan G. S. (2005) Three Component Receptance Coupling Substructure Analysis for Tool Point Dynamics Prediction. ASME Journal of Manufacturing Science and Engineering, 127 (4), 781-790. DOI: 10.1115/ 1.2039102 .

Received: 21.11.2016

Accepted: 24.01.2017

Published online: 30.05.2017

\section{ЛИТЕРАТУРА}

1. Зенкевич, О. Конечные элементы и аппроксимация / О. Зенкевич, К. Морган. М.: Мир, 1986. 312 с.

2. Браиловский, М. И. Металлобетонные базовые конструкции металлорежущих станков / М. И. Браиловский, А. Г. Воскобойник, А. А. Воскобойник. Коломна: Воентехиздат, 2010. 76 c.

3. Simon, M. Study of Improving Static Rigidity on Machine Tool Structure Using Concrete Component / M. Simon, A. L. Grama, M. Ganea // The $6^{\text {th }}$ International Conference INTER-ENG 2012. Interdisciplinarity in Engineering. Romania: "Petru Maior” University of Tîrgu Mureş, 2012. P. 26-29.

4. Довнар, С. С. Виртуальное исследование статических деформаций роторного вала в сверхтяжелом токарном станке / С. С. Довнар // Теоретическая и прикладная механика: Междунар. науч.-техн. сб. Минск: БНТУ, 2017. Вып. 32. С. 72-78.
5. Кудинов, В. А. Динамика станков / В. А. Кудинов. М.: Машиностроение, 1967.359 с.

6. Козловский, Н. А. Жесткость и виброустойчивость тяжелых фрезерных станков / Н. А. Козловский, М. П. Зайкин. Минск: Наука и техника, 1986. 135 с.

7. Баланс жесткости стойки фрезерно-сверлильно-расточного станка с симметричным расположением шпиндельной бабки / В. И. Туромша [и др.] // Вестник Гомельского государственного технического университета имени П. О. Сухого. 2012. № 3. С. 19-29.

8. Гармонический анализ порталов тяжелых продольнофрезерных станков типа «Гентри» с помощью МКЭ / С. С. Довнар [и др.] // Вестник Полоцкого государственного университета. Сер. В: Промышленность. 2014. № 11. C. 25-36.

9. Василевич, Ю. В. Модальный анализ несущей системы тяжелого горизонтального многоцелевого станка с помощью МКЭ / Ю. В. Василевич, С. С. Довнар, И. И. Шумский // Наука и техника. 2014. № 4. С.14-24.

10. Моделирование и анализ динамики несущей системы фрезерно-сверлильно-расточного станка с моностойкой / Ю. В. Василевич [и др.] // Наука и техника. 2015. № 3. C. 9-19.

11. МКЭ-анализ влияния конструктивных вариантов портала на динамику портального станка / С. С. Довнар [и др.] // Машиностроение. 2015. № 29. С. 14-22.

12. Василевич, Ю. В. Конечно-элементный анализ влияния бетонного наполнителя на динамическую жесткость портала тяжелого станка / Ю. В. Василевич, С. С. Довнар, И. А. Карабанюк // Наука и техника. 2016. T. 15, № 3. С. 233-241 .

13. Lopez de Lacalle, L. N. Machine Tools for High Performance Machining // L. N. Lopez de Lacalle, A. Lamikiz. Springer, 2009. 442 p.

14. On Stability Prediction for Milling / J. Gradišek [et al.] // International Journal of Machine Tools and Manufacture. 2005. Vol. 45, No 7-8. P. 769-781.

15. Schmitz, T. Three Component Receptance Coupling Substructure Analysis for Tool Point Dynamics Prediction / T. Schmitz, G. S. Duncan // ASME Journal of Manufacturing Science and Engineering. 2005. Vol. 127, No 4. P. 781-790.

Поступила 21.11.2016

Подписана в печать 24.01.2017 Опубликована онлайн 30.05.2017 